\title{
舌癌治療後の構音機能
}

\author{
大久保 洋 前田龍男 上村正行 \\ 渡辺陽子渡辺滋之平野実
}

\begin{abstract}
要 約 : 舌癌治療例（32例）における日本語 100 音節の発語明瞭度検查の成績と異常聴取傾向に つき検討を加え, 以下の結論を得た.

1.われわれが最近おこなっているレーザーを利用例した治療倒では, 広範手術を行った症例に 比べ明らかに発語明瞭度は良好である.レーザーによる舌部分切除の切除範囲の大小では, 術後の 発語明瞭度に差はない.

2. 舌を広範に切除する場合, 口腔底全部を含めて切除したり, 舌可動部の両側にわたる切除を 行うと発語明瞭度は低くなる.

3. 舌癌治療後の発語明瞭度が低い音節は, 弾音, 有声・無声破裂音, 無声破擦音である.

4. 舌を広範に切除した場合の異常聴取傾向をみると, 破裂音が破擦音や摩擦音, 拗音が他の拗 音として異聴されたり，拗音の子音が脱落して異聴される傾向を認める.
\end{abstract}

索引用語 : 舌癌, 構音機能, 単音節発語明瞭度

\section{Articulatory Function Following Treatments for Carcinoma of the Tongue}

\author{
Hiroshi Ohkubo, Tatsuo Maeda, Masayuki Kamimura \\ Yoko Watanabe, Shigeyuki Watanabe and Minoru Hirano
}

\begin{abstract}
Extensive surgical resection of carcinoma of the tongue results in considerable articulation disorders. In our department, a combination therapy consisting of laser surgery and radiotherapy has been attempted for the purpose of minimizing post-therapeutic articulatory disorders.

This paper describes the post-therapeutic articulatory function, comparing the post-therapeutic speech intelligibility of 100 Japanese monosyllables following extensive surgery with that following laser-radiotherapy.
\end{abstract}

Key words : carcinoma of the tongue, articulatory function, speech intelligibility

\section{I ・はじめに}

差こそあれ避けられない，呫癌の治療に执いて治癒率の 向上をはかることはもちろん大切なことであるが, 治療 後の構音障害を最小限に押えることも重要な課題の $1 つ$ である.この課題を取り扱うには，構音障害の程度を的 
Vol. 26 No. $3,1985.7$

確に評価することから始まる，その評価法の1つに単音 節発語明瞭度検查がある. そこで, 最近当教室で行った 舌癌治療例について単音節発語明瞭度検査を用い, 治療 後の構音機能について検討した.

\section{II. 研究対象および方法}

\section{1. 研究対象}

舌癌に対し手術的治療を施した 32 例を対象とした。 い ずれも1968年 7 月から1983年 3 月までの間に久留米大学 耳鼻咽喉科に拈いて治療を行った患者である．性別は男 性が23例, 女性が 9 例, 年齢は28〜 72歳である. 治療法 の内訳は, 舌半切以上の広範手術を施行した治療群（以 下，広範手術群と略す）が20例，レーザー手術と放射線 治療の併用 ${ }^{1 \sim 3}$ 群（以下，レーザー群と略す）が12例で ある.なお，広範手術群には種々の再建術を併施した 6 例が含まれる。

\section{2. 研究方法}

治療後 6 力月以上経過して（最短 6 カ月から最長 14 年 まで), 日本語 100 音節による単音節発語明瞭度検査を行 った．100音節を at random に並べて被検者に 4 秒間 隔で 1 音節ずつ提示し，それを音読させてテープに録音
した.これを 5 名の健聴者に聴取させて，正しく聴取さ れた率を発語明瞭度とした。

\section{III. 単音節発語明瞭度}

\section{100音節全体および直音, 拗音別の発語明瞭度}

広範手術群およびレーザー群の各症例における 100 音 節全体, 直音67音節, 拗音33音節の発語明瞭度を表 1, 2 の左 3 列に, 両群の比較を図 1 に示す. 図 1 は箱ヒゲグ ラフで図示したもので，個々の值の分散状態がわかる. 箱の中の長い横線は中央值を, 箱の上, 下の横線はおの おの第三，第一 4 分位数を，ヒゲの上，下端の大きな黒 丸はおのおの最高値, 最低值を示す.

100音節全体の発語明瞭度は, 広範手術群では 最高值 $92.0 \%$, 最低值 $28.2 \%$, 中央值 $75.6 \%$ とかなり広いばら つきを示す.レーザー群では最高值 $94.8 \%$, 最低值 84.4 $\%$, 中央值 $91.6 \%$ とばらつきは少ない. 両者を中央值の差 の検定 (以下, 統計学的処理はすべて中央值の差の検定 を使用)によって比較すると,危険率 $5 \%$ の有意差でもっ てレーザー群が広範手術群に比し発語明瞭度が高い.

100音節を仮名 1 文字で表される直音67音節と「きゃ， しゃ，ちゃ，」などの拗音33音節に分けて，それぞれの

表 1 単音節発語明瞭度 (広範手術群)

\begin{tabular}{|c|c|c|c|c|c|c|}
\hline & \multirow{2}{*}{ 症 例 } & \multirow{2}{*}{ 年齢・性 } & \multicolumn{4}{|c|}{ 発 語 明 瞭 度 $(\%)$} \\
\hline & & & 100 音 節 & 值音（67音節） & 拗音（33音節） & 25音節リスト \\
\hline 1. & S. S. & 64 & 78.0 & 77.6 & 78.8 & 63.2 \\
\hline 2. & T. H. & 37 & 84.2 & 89.0 & 74.5 & 83.2 \\
\hline 3. & T. A. & 42 & 92.0 & 93.7 & 88.5 & 87.2 \\
\hline 4. & K. H. & 62 & 87.6 & 91.0 & 80.6 & 80.0 \\
\hline 5. & T. H. & 57 & 80.4 & 86.5 & 67.8 & 76.8 \\
\hline 6. & H. A. & 72 & 42.4 & 49.3 & 28.5 & 27.2 \\
\hline 7. & N. Y. & 58 & 67.4 & 77.6 & 46.7 & 52.8 \\
\hline 8. & $\mathrm{~K} \cdot \mathrm{S}$. & 29 & 85.2 & 91.6 & 72.1 & 80.8 \\
\hline 9. & $\mathrm{~K} \cdot \mathrm{K}$ & 46 & 90.4 & 92.8 & 85.5 & 84.8 \\
\hline 10. & T. E. & 51 & 80.2 & 85.0 & 70.3 & 65.6 \\
\hline 11. & H. Y. & 54 & 56.0 & 63.6 & 40.6 & 36.8 \\
\hline 12. & S. K. & 49 & 74.6 & 81.5 & 60.6 & 66.4 \\
\hline 13. & K. Y. & 28 & 68.4 & 73.4 & 58.2 & 63.2 \\
\hline *14. & G. S. & 69 & 48.0 & 51.9 & 40.0 & 35.2 \\
\hline *15. & T. H. & 38 & 72.8 & 78.2 & 61.8 & 51.2 \\
\hline$* 16$. & T. S. & 65 & 83.8 & 90.1 & 70.9 & 73.6 \\
\hline *17. & K. M. & 67 & 28.2 & 34.0 & 16.4 & 0 \\
\hline *18. & I. H. & 55 & 43.0 & 61.2 & 6.0 & 22.4 \\
\hline *19. & G.N. & 51 & 76.6 & 82.1 & 65.4 & 63.2 \\
\hline 20. & K. T. & 62 & 52.0 & 57.3 & 41.2 & 28.8 \\
\hline & 平 & 均 & 69.5 & 75.3 & 57.7 & 57.1 \\
\hline
\end{tabular}


表 2 単音節発語明暸度 (レーザー群)

\begin{tabular}{|c|c|c|c|c|c|c|c|}
\hline & \multirow{2}{*}{ 症 例 } & \multirow{2}{*}{\multicolumn{2}{|c|}{ 年齢・性 }} & \multicolumn{4}{|c|}{ 発 語 明 瞭 度 （\%) } \\
\hline & & & & 100 音 節 & 直音（67音節） & 拗音（33音節） & 25音節リスト \\
\hline 1. & M. K. & 47 & 女 & 88.2 & 88.1 & 88.5 & 84.0 \\
\hline 2. & G. K. & 47 & 男 & 93.6 & 95.2 & 90.3 & 94.4 \\
\hline 3. & F. K. & 60 & 男 & 93.2 & 93.4 & 92.7 & 91.2 \\
\hline 4. & K. N. & 59 & 男 & 93.8 & 97.3 & 86.7 & 96.0 \\
\hline 5. & M. H. & 67 & 男 & 91.0 & 93.7 & 85.4 & 81.6 \\
\hline 6. & E. N. & 54 & 女 & 94.8 & 93.1 & 98.2 & 89.6 \\
\hline 7. & D. S. & 51 & 男 & 91.4 & 95.8 & 82.4 & 89.6 \\
\hline 8. & K. F. & 57 & 男 & 93.0 & 94.3 & 90.3 & 88.0 \\
\hline 9. & E. I . & 42 & 女 & 89.6 & 91.9 & 84.8 & 84.0 \\
\hline 10. & T. Y. & 61 & 男 & 84.4 & 87.2 & 78.8 & 79.2 \\
\hline 11. & Y.M. & 66 & 男 & 90.8 & 95.2 & 81.8 & 88.8 \\
\hline 12. & Y.H. & 54 & 男 & 91.8 & 94.3 & 86.6 & 93.6 \\
\hline & 平 & 均 & & 91.3 & 93.2 & 87.2 & 88.3 \\
\hline
\end{tabular}

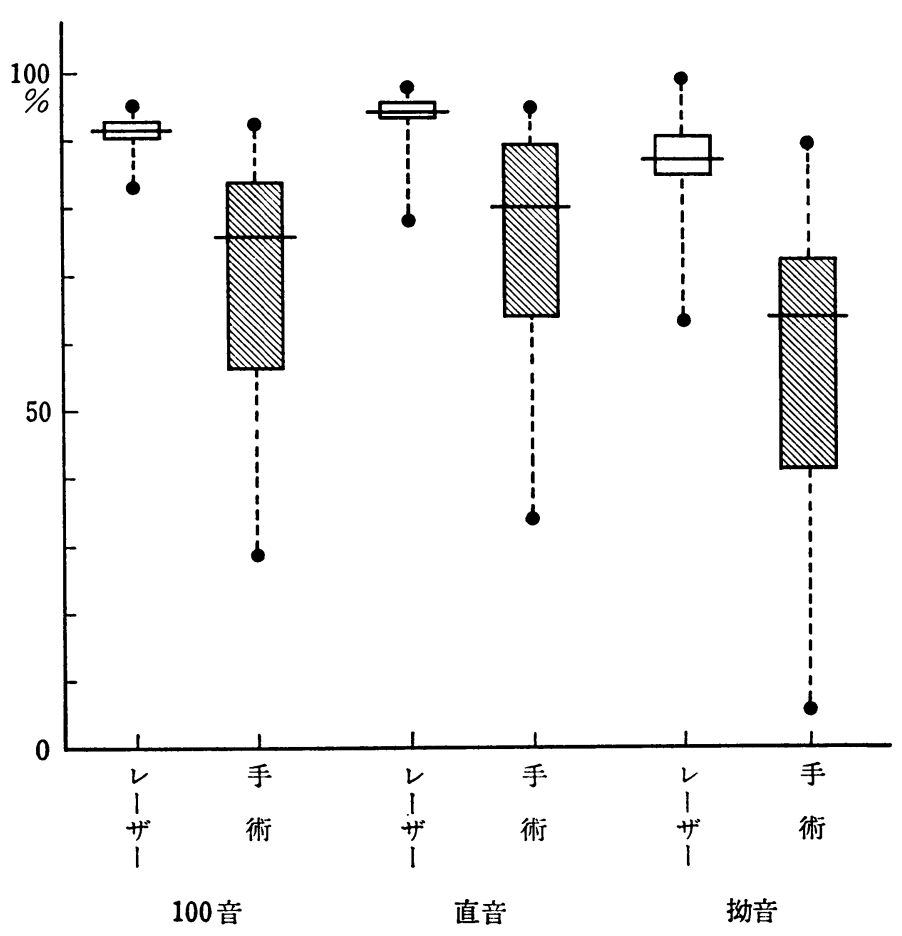

図 1 単音節発語明瞭度

発語明瞭度を検討する. 広範手術群では直音は最高值 $93.7 \%$, 最低值 $34.0 \%$, 中央値 $79.8 \%$ で，拗音は最高値 $88.5 \%$, 最低值 $6.0 \%$, 中央値 $63.6 \%$ である. 危険率 5 \%の有意差で拗音は直音に比し発語明瞭度が低い、レー ザー群では直音は最高値 $97.3 \%$, 最低值 $87.2 \%$, 中央値 $94.0 \%$ で, 拗音は最高値 $98.2 \%$, 最低値 $78.8 \%$, 中央值 86. $6 \%$ である. 広範手術群と同様に, 危険率 $5 \%$ の有意 差で拗音は直音に比し発語明瞭度が低い. 以上のことか
ら, 舌癌の手術後には一般に切除範囲の多少にかかわら ず，直音より拗音の方が発語明瞭度は低いといえる.

\section{2. 切除範囲別の発語明瞭度}

広範手術群の 20 例のうち再建術を行った 6 例を除く 14 例の切除範囲は次のごとく分けられる.

$\mathrm{A}$ : 舌可動部半側の切除 (口腔底の一部を含めて切除 した例を含む）；8例

$\mathrm{B}$ : 舌可動部半側と口腔底の全部を切除； 5 例 


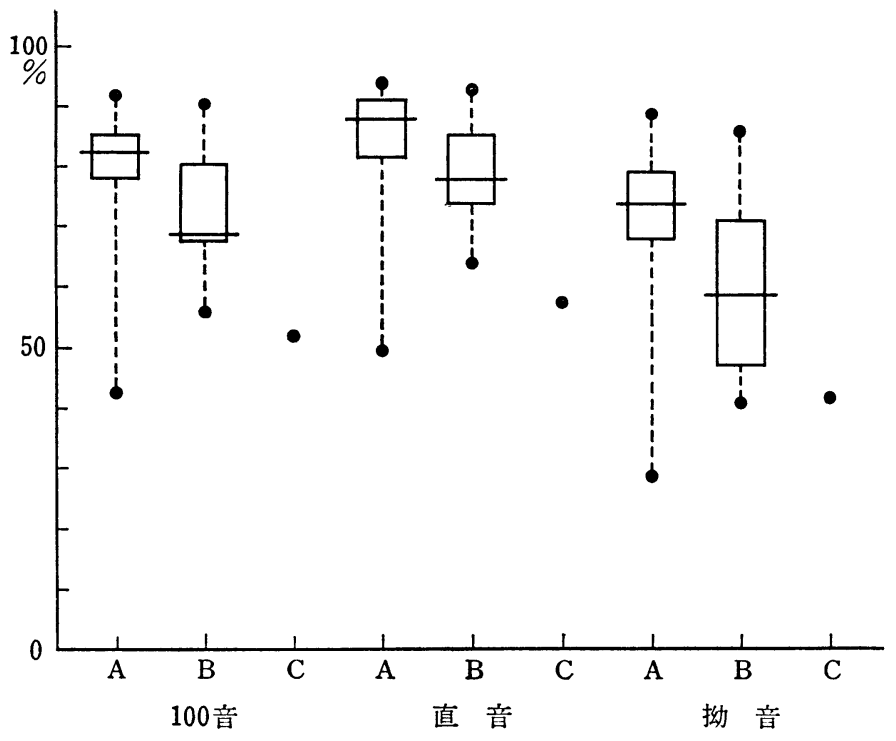

図 2 切除範囲別の単音節発語明膫度

\section{$C$ : 舌可動部の半側を越えた切除； 1 例}

切除範囲別の 100 音節全体, 直音, 拗音の発語明瞭度 を図 2 に示す。1 100 音節全体の発語明瞭度は, 切除範囲 Aでは最高值 $92.0 \%$, 最低值 $42.4 \%$, 中央值 $82.3 \%$ で, 切除範囲 Bでは最高值 $90.4 \%$, 最低值 $56.0 \%$, 中央值 68. $4 \%$ である. 両者を比較すると危険率 $5 \%$ の有意差で 切除範囲 $\mathrm{A}$ の方が発語明瞭度が高い，直音の発語明瞭度 は, 切除範囲 $\mathrm{A} て ゙ は$ 最高值 $93.7 \%$, 最低值 $49.3 \%$, 中 央值 $87.7 \%$ で, 切除範囲 B では最高值 $92.8 \%$, 最低值 $63.6 \%$, 中央値 $77.6 \%$ である. 両者を比較すると危険率 $5 \%$ の有意差で切除範囲 Aの方が発語明瞭度が高い. 拗

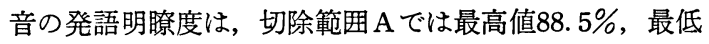
值 $28.5 \%$, 中央值 $73.3 \%$ で, 切除範囲 Bでは最高值 85.5 $\%$, 最低值 $40.6 \%$, 中央值 $58.2 \%$ である. 両者を比較 すると危険率 $5 \%$ の有意差で切除範囲 Aの方が発語明瞭 度が高い。また，切除範囲 Cは 1 例であるが，100 音節 全体の発語明瞭度が $52.0 \%$, 直音が $57.3 \%$, 拗音が 41.2 \%で，切除範囲 $\mathrm{A}$ と Bのそれぞれの発語明瞭度の第一 4 分位数よりも明らかに小さい. 以上のことから, 舌癌に 対し広範手術を行う場合, 舌可動部半側の切除で口腔底 を一部含めて切除するよりも, 舌可動部半側と口腔底全 部を含めて切除する方が術後の発語明瞭度は低いといえ る. すなわち, 舌可動部の半切では, 口腔底を一部含め て切除するか全部切除するかで, 術後の発語明瞭度に大 きな影響を及ぼす.また, 舌可動部半側の切除に比べて 舌可動部の半側を越えて切除した場合, すなわち舌尖部 を含めた切除を行うと術後の発語明瞭度は低くなる.
次にレーザー群における切除範囲別の発語明瞭度を検 討する.レーザーで舌部分切除を行う場合には, 通常癌 の辺縁に健常部を約 $1 \mathrm{~cm}$ つて切除している ${ }^{1 \sim 3)}$. そこ でT 1 と T 2 症例では T 2 の方が切除範囲が大きいと仮 定して, それぞれの発語明瞭度を比較した。 レーザー群 12例の $\mathrm{T}$ 分類による内訳は $\mathrm{T} 1$ が 8 例， T 2 が 4 例であ る. $\mathrm{T}$ 分類別の 100 音節全体, 直音, 拗音の発語明瞭度 を図 3 に示す． 100 音節全体の発語明瞭度は，T 1 では 最高值 $93.8 \%$, 最低值 $88.2 \%$, 中央値 $91.2 \%$ で, T 2 で は最高值 $94.8 \%$, 最低值 $84.4 \%$, 中央値 $92.4 \%$ である. 両者を比較すると危険率 $5 \%$ では有意差を認めない，直 音の発語明瞭度は, T 1 では最高值 $97.3 \%$, 最低值 88.1 $\%$, 中央値 $94.4 \%$ で, T 2 では最高值 $94.3 \%$, 最低值 $87.2 \%$, 中央值 $93.7 \%$ である. 両者を比較すると危険率 $5 \%$ では有意差を認めない. 拗音の発語明瞭度は, T 1 では最高值 $92.7 \%$, 最低值 $81.8 \%$, 中央値 $86.0 \%$ で, $\mathrm{T}$ 2 では最高值 $98.2 \%$, 最低值 $78.8 \%$, 中央值 $88.4 \%$ で ある. 両者を比較すると危険率 $5 \%$ では有意差を認めな い. 以上のことから，レーザーによる舌部分切除を行ら 場合には, 切除範囲の大小にかかわらず術後の発語明膫 度に有意の差はないといえる。

\section{3. 舌癌治療後に発語明瞭度の低い音節}

対象とした 32 例に抢ける 100 音節の発語明瞭度（32例 の平均) のなかで, 明瞭度の低い音節から順に50音節を 並べると表 3 のとおりである．その内訳を直音と拗音に 分けると, 直音が 21 音節, 拗音が 29 音節で拗音の方が多 い. 最も明瞭度の低い音節は“ぎゅ”で $40.0 \% ， 50$ 番目 


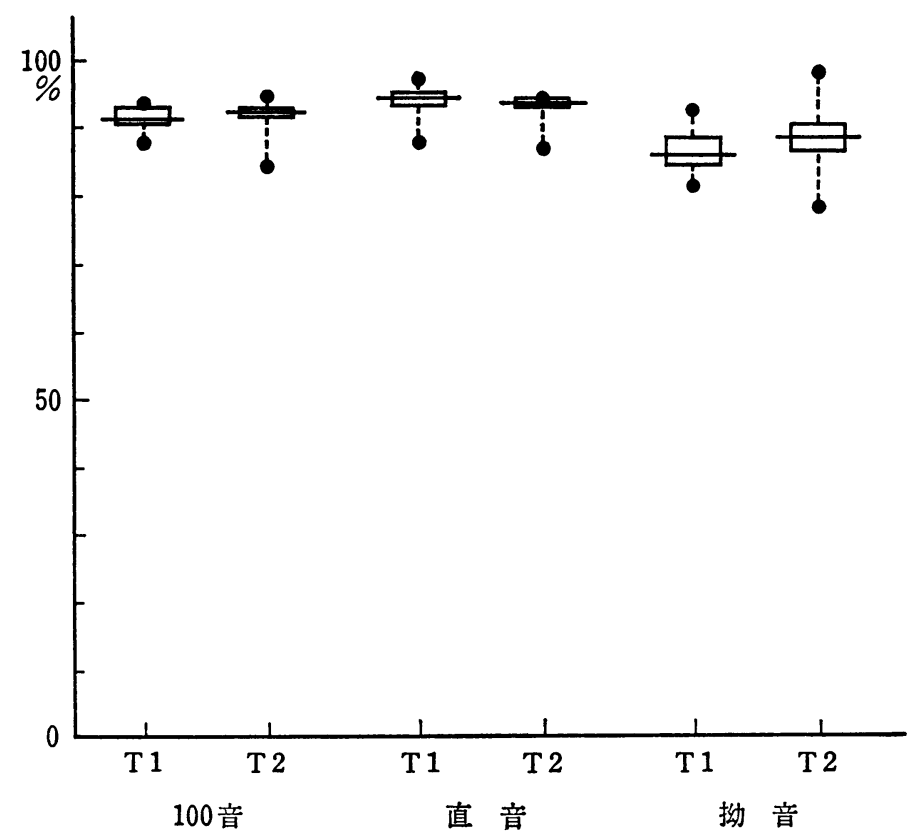

図 3 T分類別の単音節発語明瞭度 (レーザー群)

表 3 発語明瞭度の低い50音節

\begin{tabular}{|c|c|c|c|c|c|c|c|c|}
\hline 順 位 & 音 節 & $\begin{array}{c}\begin{array}{c}* \\
\text { 発語明瞭度 } \\
(\%)\end{array} \\
\end{array}$ & 順 位 & 音 節 & 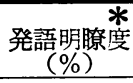 & 順 位 & 音 節 &  \\
\hline 1. & ぎゅ & 40.0 & 21. & みよ & 67.5 & 41. & と & 75.0 \\
\hline 2. & り片 & 42.5 & 22. & $\eta$ & 68.1 & 42. & ヘำ & 75.0 \\
\hline 3. & で & 43.7 & 23. & ご & 68.7 & 43. & ちょ & 75.0 \\
\hline 4. & だ & 46.8 & 24. & み & 68.7 & 44. & る & 75.6 \\
\hline 5. & ぎ & 51.2 & 25. & じゅ & 69.3 & 45. & $<$ & 76.2 \\
\hline 6. & ど & 53.1 & 26. & じょ & 69.3 & 46. & ぴゃ & 76.2 \\
\hline 7. & ぎゃ & 56.2 & 27. & け & 69.3 & 47. & ひ & 76.8 \\
\hline 8. & りょ & 57.5 & 28. & ぴよ & 71.2 & 48. & Lゃ & 76.8 \\
\hline 9. & ぎょ & 58.1 & 29. & び & 71.2 & 49. & に & 78.1 \\
\hline 10. & $\eta や$ & 58.7 & 30. & ひゃ & 71.8 & 50. & しゅ & 78.1 \\
\hline 11. & た & 59.3 & 31. & れ & 71.8 & & & \\
\hline 12. & き⿰氵 & 60.6 & 32. & びょ & 72.5 & & & \\
\hline 13. & ちゅ & 61.2 & 33. & みゃ & 72.5 & & & \\
\hline 14. & きょ & 62.5 & 34. & ぴゅ & 73.1 & & & \\
\hline 15. & み:D & 62.5 & 35. & にゅ & 74.3 & & & \\
\hline 16. & $\tau$ & 63.1 & 36. & $ひ_{\Phi}$ & 74.3 & & & \\
\hline 17. & き & 66.2 & 37. & ぐ & 74.3 & & & \\
\hline 18. & ちゃ & 66.2 & 38. & げ & 74.3 & & & \\
\hline 19. & きゃ & 66.8 & 39. & びゅ & 75.0 & & & \\
\hline 20. & ひょ & 66.8 & 40. & じゃ & 75.0 & & & \\
\hline
\end{tabular}

32 症例の平均值

の音節は “しい”で78.1\%，この間に明瞭度の $40 \%$ 台が 4 音節， $50 \%$ 台が 7 音節，60\%台が16音節，70\%台が 23 音節含まれる.これらの音節を構音方法別に分けて検討 してみた。 日本語 100 音節は構音方法により，母音（5
音節), 半母音 ( 4 音節), 弾音 ( 8 音節), 通鼻音 ( 16 音節), 無声摩擦音 (16音節), 無声破裂音 (19音節), 有声破裂音 (19音節), 無声破擦音 ( 5 音節), おょび有 声破擦音（8 音節）に分けられる ${ }^{4)}$ 。このらち発語明瞭 
度の低い音節を多く含むのは，弾音 (6/8), 有声破裂 音 (13/19), 無声破擦音 (3/5), 無声破裂音 (10/19) で ある．ここで全32例の構音方法別発語明膫度の平均を低 い順に並べると, 弾音 $(72.0 \%)$, 有声破裂音 $(73.0 \%)$, 無声破裂音 $(77.9 \%)$, 無声破擦音 (78.6\%), 通鼻音 $(83.0 \%)$, 有声破擦音 $(84.3 \%)$, 無声摩擦音 (87.2 $\%)$, 半母音 $(90.4 \%)$, 母音 $(94.4 \%)$ となる. 以上の ことから, 舌癌治療後の構音方法別発語明瞭度は弾音, 有声・無声破裂音, 無声破擦音で低い傾向にあるとい兄 る.

次に明膫度の低い音節を構音部位別に分けて検討して みた，日本語 100 音節は構音部位により，両唇音，歯茎 音, 硬口蓋音, 軟口蓋音, および声門音に分けられる このうち発語明瞭度の低い音節は, 両唇音, 歯茎音, 硬 口蓋音，軟口蓋音に含まれているが，それぞれの間には 明らかな差はみられない。なお，声門音には含まれてい ない，そこで全32例の構音部位別発語明瞭度の平均を低 い順に並べると，軟口蓋音（71.9\%)，硬口蓋音（78.0 $\%)$, 歯茎音 $(78.4 \%)$, 両唇音 $(83.6 \%)$, 声門音 $(96.4$ \%)となる. 以上のことから, 舌癌治療後の構音部位別 発語明瞭度は声門音では高いが，その他の音では明らか な差はなく，ぞれが低いとはいえない。

\section{IV. 異常聴取傾向}

舌癌治療後の構音では正しく聴取されない音節が多 い. その場合，どんな音節がどのように異聴される傾向 があるかを異聴マトリックス（Confusion Matrix）を作 って検討した、レーザー群では全般的に発語明膫度が高 く, 5 名の健聴者が異聴した音節が少ないので明確な異


しての異聴傾向を述べる. 100 音節において 5 名の健聴 者全員に異聴された音節のうち, 被検者全体の $1 / 4$ 亿相 当する 5 名か，それ以上に異聴を認めたものは 26 音節で ある．その内訳は直音11音節と拗音15音節である．これ
を構音方法別に並べると，無声破裂音“た，て，き， く、けきゃきゅきょ，ぴゅぴょ”，有声破裂音 “だ,で，どぎぎやぎゅぎょ”弾音“り，り や，り虫りょ”，通鼻音“み，及心”，無声破擦音“ち 心”, 有声破擦音“じゅ”, および無声摩擦音“ひょ”の 26音節である。これらのらち主な異聴傾向をまとめて表 4 亿示す．無声破裂音“た，て”は無声破裂音“ぱ，へ”” と無声摩擦音“さ，せ”, 無声破裂音“きゃ，きゅ，きょ” は無声摩擦音“ひゃ，ひゅ，ひょ”之無声破擦音“ちゃ， ちゅ,ちょ”に異聴される傾向がある．有声破裂音 “だ，でど”は有声破擦音“ざ，ぜ，ぞ”と有声破裂 音 “ば, ベ，ぼ”，有声破裂音“ぎ”は有声破擦音“じ”， 有声破裂音“ぎゃ，ぎ，ぎょ”は有声破擦音“じゃ， じゅ，じょ”之弾音“りゃ，りゅ，りょ”拉よ゙゙半母音 “や，ゆ，よ”に異聴される傾向がある．弾音“り”は 有声破擦音 “じ”之有声破裂音 “び”，弾音“りゃ，り 中，りょ”は半母音“や，ゆ，よ”と有声破裂音“びゃ， びゅ,びょ”および有声破擦音“じゃ，じゅじょ”に 異聴される傾向がある.すなわち舌癌手術後の構音の異 聴傾向としては, 破裂音が破擦音や摩擦音, 拗音が他の 拗音として聴かれたり，拗音の子音が脱落して聴かれる 傾向がみられる。

\section{$\mathrm{V}$. 発語明瞭度検査用の25語音リスト}

今回おこなった日本語 100 音節による発語明瞭度検査 の利点としては，正しく聴取された音節数を数えるだけ でただちに百分率が求められ算出が容易であること，ま た異聴傾向を検討するための異聴マトリックス(Confusion Matrix)を作られることである.しかし欠点は，語 音サンプルが多いので患者が疲労しやすく，また検査結 果が出るまでに長時間（最低 1 時間）を要することであ る.したがって日常臨床の検查法としては実用的ではな いと考学る. そこで比較的簡便に発語明瞭度検查を行う ための 25 語音リストを考案した。この 25 語音の選定のた

表 4 異常聴取傾向

\begin{tabular}{|c|c|c|c|c|c|}
\hline & & 直 & 音 & & \\
\hline た & $\tau$ & & $\begin{array}{l}\text { ぱ } \\
\text { さ }\end{array}$ & ペ & \\
\hline だ & で & ど & $\begin{array}{l}\text { ざ } \\
\text { ば }\end{array}$ & $\begin{array}{l}\text { ぜ } \\
\text { ベ }\end{array}$ & $\begin{array}{l}\text { ぞ } \\
\text { ぼ }\end{array}$ \\
\hline ぎ & & & じ & & \\
\hline$\eta$ & & & $\begin{array}{l}\text { じ } \\
\text { び }\end{array}$ & & \\
\hline
\end{tabular}

\begin{tabular}{|c|c|c|c|c|c|}
\hline & & 拗 & 音 & & \\
\hline りゃ & りゅ & りょ & $\begin{array}{l}\text { や } \\
\text { びゃ } \\
\text { じゃ }\end{array}$ & $\begin{array}{l}\text { ゆ } \\
\text { びゅ } \\
\text { じゅ }\end{array}$ & $\begin{array}{l}\text { よ } \\
\text { びょ } \\
\text { じょ }\end{array}$ \\
\hline ぎや & ぎゅ & ぎょ & $\begin{array}{l}\text { ごゃ } \\
\text { りゃ } \\
\text { や }\end{array}$ & $\begin{array}{l}\text { じゅ } \\
\text { りゆ } \\
ゆ\end{array}$ & $\begin{array}{l}\text { じょ } \\
\text { りょ } \\
\text { ょ }\end{array}$ \\
\hline きゃ & きゅ & きょ & $\begin{array}{l}\text { ひゃ } \\
ち ゃ\end{array}$ & $\begin{array}{l}\text { ひゅ } \\
\text { ちゅ }\end{array}$ & $\begin{array}{l}\text { ひょ } \\
ち ょ\end{array}$ \\
\hline
\end{tabular}


表 525 語音リスト

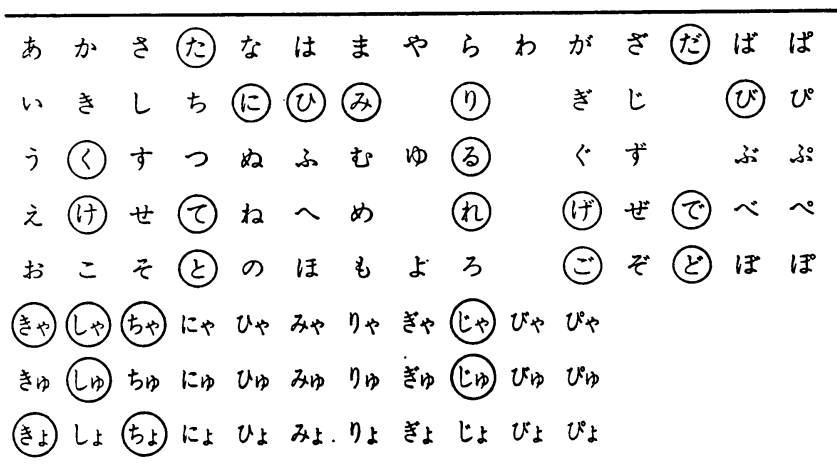

めの資料としては, 全32例の 100 音節による発語明瞭度 の成績を使用し, 次の事項を勘案して語音リストを作製 した.

1）舌癌手術後に構音障害をおこしやすい語音をなる ベく多く入れる.

2）日常会話で用いられる頻度（会話率）の高い語音 をなるべく多く入れる.

3）選んだ語音リストによる発語明瞭度が 100 音節全 体の発語明瞭度と高い相関を有する.

4）正常者でも昰んだ構音をしやすい語音は含まな W.

実際に語音を選定する作業の詳細は別に報告してい る5)ので割愛し，25語音リストのみを表 5 に示す．この 25音節の発語明瞭度を 100 音節の発語明瞭度検査の成績 のなかから抜き出して算出すると, 表 1，2 の右 1 列の ようになる.なお,この 25 音節と 100 音節の発語明瞭度 との相関係数は 0.98 である.

\section{VI. 考按}

舌癌の治療に関しては治瘉率の向上をはかることはも ちろんではあるが, 治療後の構音障害を極力抑えること も大切なことである. 我々の教室では1979年までは広範 手術を主体とした治療を行っていだ,7)が, 術後に種々 の程度の構音障害を免れることができなかった。 そこで 治癒率を低下させることなく構音障害を遺さないことを 目的として，1980年よりレーザー手術と放射線療法の併 用を行っている ${ }^{1 \sim 3)}$. 今回, 広範手術群とレーザー群に ついて単音節発語明瞭度を検討したが，100 音節全体で も, 直音・拗音別でも, レーザー群の方が広範手術群に 比べ明らかに高い発語明瞭度を有している. しかもレー ザー群における 100 音節の発語明膫度は全例 $90 \%$ 前後と 高く，これは日常会話がほとんど正常にできる高さとい える.この治療法を始めて 1985 年 3 月までの 5 年生存率
は83. $8 \%$ と高く, 局所再発例は 1 例もない. 従って治癒 率を低下させず, 構音障害を遺さないという当初の目的 は達成されており, 将来性のある治療法と考える。

舌癌に対し手術的治療を行った場合, 術後の構音障害 の程度は切除範囲と関係があることは容易に推察でき る. 特に舌可動部と舌根部における切除範用だけではな く, 口腔底や下顎骨の切除範囲もそれぞれ術後の構音機 能と密接に関係している.これまで舌癌治療後の構音機 能に関する報告は多いが, 切除範团別の構音障害の程度 について検討したものは少ない,8,9). われわれの舌可動 部半切を最小限の切除とする広範切除を行った14例につ いて検討すると, 舌可動部半切の場合には口腔底全部を 含めて切除すると明らかに発語明瞭度が低いことがわか った. また舌可動部の両側にわたる舌可動部前部の切除 でも発語明瞭度が低かった. これは舌切除後の構音機能 には, 舌の volume の不足だけではなく残存舌の可動性

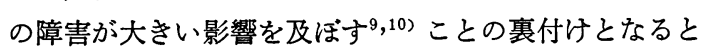
考える. なお, 舌根部や下顎骨の切除範囲と構音障害の 程度との関係については，今回は該当する症例がなく検 討できなかった，今後さらに検討を加えたい.

レーザー群において舌部分切除を行う場合, 当然 T 1 より T 2 症例の方が切除範囲は大きくなるはずである. しかし術後の発語明瞭度には両者の間に有意の差を認め なかった. したがって現在われわれが行っているレー ザー手術では T 1 と T 2 を適応とする限り, 切除範囲の 大小では術後の発語明瞭度に差はないと思われる. しか しレーザーによる舌部分切除例と広範手術後の舌可動部 半切例との間には明らかに発語明瞭度に差があると思わ れるので, この両者の切除範囲の間に発語明瞭度を左右 する切除限界があると考える.これについても今後の検 討が必要である.

最近の再建外科の進歩に伴い, 舌を広範に切除した場 合, 種々の再建法が試みられている. しかし再建後の構 音機能に関する諸家の報告をみても, 必ずしも満足でき 


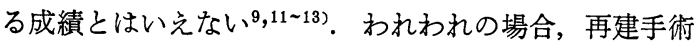
を行った 6 例の 100 音節発語明瞭度は $28.2 \sim 83.8 \%$ で, このうち 3 例が $50 \%$ 以下であった. 熊倉 ${ }^{9}$ ( は舌半切の場 合, 再建の有無, あるいは方法によって構音能力に極端 な差がないと述べている.われわれは舌可動部半切の場 合に限っては再建の必要はないとの印象をもっている. しかし舌可動部半切を越えた切除を行う場合は再建術が 必要で, この場合にはどのような皮弁や筋皮弁を使打う とも残存舌の可動性を障害しないような再建法の配慮が 重要と考えている.

舌癌治療後の構音では正しく聴取されない音節が多 い.そこで発語明膫度の低い音節を検討すると，構音方 法別では弾音, 有声 - 無声破裂音, 無声破擦音で低い傾 向にあった．これは諸家の報告とほぼ一致するところで ある ${ }^{8,12 \sim 14)}$. そこで異常聴取傾向を検討すると，破裂音 が破擦音や摩擦音，拗音が他の拗音として聴かれたり， 拗音の子音が脱落して聴かれる傾向がみられた，それで はどうしてこのような異常聴取傾向がみられるかを分析 するためには，ダイナミックパラトグラフィーで舌の構 音動態を検討する必要があると考光，現在，取り組んで いるのでその一端を紹介する／ $/ \mathrm{t} / \mathrm{d} / \mathrm{d} /$ の歯荃破裂音で は，正常例は，舌が歯槽部，あるいは口蓋に接触して口 腔内圧を高めたのち，タイミングよく舌尖が離れ呼気破 裂が行われる. ところが舌半切例では舌の最大接触面積 が正常例と比べ小さく, 接触開始時から音産出時までの 時間が短いことがわかった．このことから舌半切例では 呼気破裂に必要な口腔内圧が十分に高まらないため，破 裂音が破擦化されたり，摩擦化されると考元た．また弾 音 $/ \mathrm{rja} /$ では，正常例では舌尖を反転挙上し，口蓋を前 方に弾くように接触するパターンがみられる。これに対 して舌半切例では最大接触面積は正常例と比べ非常に小 さく，接触時間も短いことが認められた。 したがって舌 半切例では子音が脱落し, 後続の/ja/の影響が強く現れ て/ja/亿異聴されやすいと考光た，今後，さらに症例を 增やして検討を加え，稿を改めて報告したい．

舌癌治療後の構音検査法としては単音節検査, 単語検 査，文章検査，および会話検查などがあり，それぞれ長 所と短所をるっている．単音節は日本語の基本となる語 音の単位であり，これを用いると「ことば」の明膫性を 発語明瞭度として定量的に表現することができる ${ }^{15}$. 単 音節を用いる場合に問題となるのは, 用いる音節の数と 種類をどのようにして選定するかである. 100 音節すべ てを用いるのは，実地臨床上時間がかかりすぎて好まし くない.そこで実際の臨床例から得られたデータにもと づいて発語明瞭度検查用の 25 語音リストを作製した。 こ の25語音の選定にあたっては舌癌治療後の構音障害を敏
感に反映するとともに, 会話率を加味して日常会話にお ける障害もある程度反映するように考慮した。

\section{VII. ま と め}

舌癌の治療を行った 32 例について日本語 100 音節の発 語明瞭度検査を施行し，その成績をもとに舌癌治療後の 構音機能について検討を加えた。

1. 厷範手術群とレーザー群に分けると, 治療後の発 語明膫度は明らかにレーザー群の方が良好であった。

2 . 切除範囲別の発語明瞭度は, 広範手術群では口腔 底全部を含めて切除したり，舌可動部の両側にわたる切 除を行らと明瞭度が低值を示した．レーザー群では切除 範囲の大小で発語明瞭度には差を認めなかった。

3 . 発語明瞭度の低い音節は, 構音方法別では弾音, 有声・無声破裂音，無声破擦音であった。

4. 異常聴取傾向をみると, 破裂音が破擦音や摩擦 音，拗音が他の拗音として異聴されたり，拗音の子音が 脱落して異聴される傾向を認めた。

5. 舌癌治療後の発語明瞭度を実地臨床上簡便に検查 できる25語音リストを作製した。

\section{文献}

1) 平野 実, 他 : 口腔癌の治療におけるレーザーの利 用. 日癌治, $18: 896-899,1983$.

2 ) 平野 実, 他：舌癌に対する adjuvant laser therapy. 耳鼻臨床, $76: 883-889,1983$.

3 ) 平野 実, 他: 舌癌の治療に打ける $\mathrm{CO}_{2}$ レーザー の利用とその成績. 日本レーザー医学会誌，5： 497-500, 1985.

4) 服部四郎：音声学. 岩波全書, 東京, 1951.

5 ) 大久保 洋, 他: 舌癌手術後の構音検査, 発語明瞭 度検査用の 25 語音リストの提案. 日耳鼻, 投稿中.

6 ) 平野 実, 他: 舌癌の治療. 耳鼻臨床, $72: 333-$ 343, 1979.

7) Ohkubo. H., et al. : Carcinoma of the lip and oral cavity. A retrospective investigation of 113 patients. Kurume Medical Journal., $29: \mathrm{s} 61-78$, 1982.

8 ) 柳野権次郎, 他 : 舌半側切除と音声言語. 日耳鼻, $66: 512-517,1963$.

9 ) 熊倉勇美: 舌癌術後の構音障害について (その 3 ). 音声言語, $26: 83,1985$.

10）澤島政行, 他 : 舌切除後の言語機能. 音声言語, 13 : 86, 1972. 
11）今野昭義, 他 : 舌亜全摘術後の構音能. 頭 頚 部 腫 瘍, $3: 102,1976$.

12）糟谷政代, 他 : 舌癌摘出症例の構音障害—1 1 全 摘による無舌の 1 例—— 日口外誌, $27: 363-372$, 1978.

13）熊倉勇美, 他 : 舌癌術後の構音能力の回復経過. 音 声言語, $24: 98-99,1983$.

14）江口実美, 他: 舌癌手術例の speech motor function について. 頭頸部腫瘍, $3: 101,1976$.
15）岡本途也, 他 : 語音発語明瞭度検査法について. 耳 喉, $28: 587-591,1956$.

別刷請求先: $\mathbf{\boldsymbol { T }} 830$ 福岡県久留米市旭町 67 久留米大学耳鼻咽喉科学教室 大久保 洋 